University of Nebraska - Lincoln

DigitalCommons@University of Nebraska - Lincoln

Faculty Publications in Educational

Administration

Educational Administration, Department of

2020

\title{
What HRD Is Doing-What HRD Should be Doing: The Case for Transforming HRD
}

Richard J. Torraco

Henriette Lundgren

Follow this and additional works at: https://digitalcommons.unl.edu/cehsedadfacpub

Part of the Educational Administration and Supervision Commons

This Article is brought to you for free and open access by the Educational Administration, Department of at DigitalCommons@University of Nebraska - Lincoln. It has been accepted for inclusion in Faculty Publications in Educational Administration by an authorized administrator of DigitalCommons@University of Nebraska - Lincoln. 


\title{
What HRD Is Doing-What HRD Should be Doing: The Case for Transforming HRD
}

\author{
Richard J. Torraco ${ }^{1}$ and Henriette Lundgren ${ }^{2}$ \\ 1 University of Nebraska-Lincoln, USA \\ 2 Corning Inc., Ithaca, NY, USA \\ Corresponding author - Richard J. Torraco, Department of Educational Administration, \\ College of Education and Human Sciences, University of Nebraska-Lincoln, \\ 120 Teachers College Hall, Lincoln, NE 68588-0360, USA. \\ Email: rtorraco1@unl.edu \\ ORCID - Richard J. Torraco https://orcid.org/000o-0003-2952-1267
}

\begin{abstract}
Human resource development (HRD) is no longer expected to be the primary agency for promoting learning and development among employees. Today, HRD is diffused and integrated into a broad range of leadership and supervisory roles. As more responsibility for learning and development is assumed by others, what is the role of HRD? Although HRD has largely adapted to sharing more of its traditional responsibility for learning and development, the field has also encountered challenges and criticisms. We juxtapose recent adaptations and advances in HRD with perspectives on the dilemmas, challenges, and criticisms of HRD as seen by those outside the field of HRD. Grounded in a comprehensive review of recent literature, the authors seek to provide a balanced perspective on HRD's strengths and weaknesses and to conceptualize a new perspective on HRD and its transformation for the future.
\end{abstract}

Keywords: criticisms of HRD, accomplishments of HRD, change in HRD

Published in Human Resource Development Review 2020, Vol. 19(1) 39-65

DOI: $10.1177 / 1534484319877058$

Copyright (C) 2019 Richard J. Torraco and Henriette Lundgren. Published by SAGE Publications. Used by permission. 


\section{A Day in the Life of a Human Resource Development (HRD) Professional Today}

It is a day like every day. Natasha, product innovation manager at a large tech company based in Philadelphia, starts her day with short, online-hosted learning snacks with the company's design team based in Central Asia and North Africa. Working at an organization that operates within a global network, Natasha promotes virtual collaboration among employees enabling them to work together on projects regardless of time or location. She logs in remotely from home and facilitates the learning conversation in a cross-functional and cross-cultural setting. Today's topic looks at innovation through virtual teamwork. After finishing her meeting notes and video edits, Natasha sends the content to the communications team who broadcasts the recording on the company's intranet for all employees to watch. On her way into work, Natasha receives a phone call from her boss, the vice president of product development, who considers Natasha's work vital to business success. She asks her to review the leadership competency model in preparation for the company's new growth strategy. Natasha makes a note to do that in the afternoon, with a focus on the resilience, creativity, and systems thinking competencies.

Upon entering the office, Natasha first checks in with the organization development team that has been preparing the launch of a companywide microlearning platform that integrates new product innovation-related content with the existing learning management system (LMS). Relying on her firsthand knowledge of the company's technology-based products and workplace, she and her team members check the project plan together, including the key stakeholder engagement milestones and agile rollout methodology that the company has adopted for all management of change projects. Natasha is excited about the new integrated coaching app, an application of recent research, which uses artificial intelligence to help employees with their public speaking and team management coaching. The morning flies by in no time, and after kicking-off a Lunch ' $\mathrm{n}$ Learn session on volatility, uncertainty, complexity, and ambiguity together with the research team, Natasha retreats to her mobile office pod to review last month's scorecard. Recognizing the importance of demonstrating people development effectiveness, she spends some time on putting together the narrative that supports the return on investment (ROI) 
numbers for the company's global leadership development program. Finally, it is time to meet for her talk walk coaching sessions that she conducts as a peer-to-peer event with the sales team in the nearby park-a great way to decelerate from the fast pace and always-connected work environment.

As illustrated by Natasha's important but demanding job, the pace of change at work is accelerating, and employees are expected to adapt. Hardy (2016) cited the expectations of leaders who want the advantage of being first to the marketplace: "All the layers and specialization are breaking down. Instead of a year, we want to put an idea in front of a customer in a week" (p. 3). Another executive stated,

We don't talk about work/life balance anymore. It's work/life mix. If you need to be home at $4 \mathrm{p}$.m., then put your kid to bed and make up for it at 10 p.m., that's fine. Younger people now want flux in their day, and they don't want to turn off the information, ever. (Hardy, 2016, p. 4)

Although Natasha is a line manager, she is expected to promote the learning and development of her employees. How well are line managers of all functions meeting the personal and emotional needs of employees who must function in an environment where the information (and expectations) are never turned off? With more multinational organizations conducting business across multiple time zones in the global economy, employees are expected to stay ahead of commercial transactions that occur around the clock and around the globe (Deloitte, 2016).

\section{Problem Statement}

The expertise for HRD was once the responsibility primarily, and sometimes exclusively, of the HRD professional. This is no longer the case. Managers and others with supervisory responsibilities such as Natasha are expected to promote learning, continuous development, collaboration, and teamwork among employees. That is, managers with non-HRD backgrounds are assuming more responsibility for learning and development (Cappelli \& Tavis, 2018; Whittaker \& Marchington, 2003). So, what is the role of HRD in an environment in 
which the responsibility for promoting learning is diffused and integrated into a broad range of leadership and supervisory roles? What does HRD do? In fact, what is HRD in this environment? Is HRD as we know it even needed at all? Today, as more responsibility for learning and development is assumed by others, what is the role of HRD?

We examine HRD's responsiveness to five factors that are affecting dramatic change in the environment and reshaping the future of HRD: technology, economics and financial considerations, globalization, equality of opportunity, and the changing nature and organization of work. In response to these changes, HRD's identity has evolved through adaptations and advances in the field. The literature is reviewed to explore how HRD has adapted to, and taken advantage of, recent changes in technology and in response to the effects of economics and financial considerations, globalization, the need for diversity, inclusiveness, and opportunity in the workplace, and in response to the changing nature and organization of work.

However, HRD has also faced dilemmas, challenges, and criticisms of how it meets the needs of those it is intended to serve. These include criticisms of the lack of strategic alignment of HRD, that HRD offers programs of marginal value at the expense of those that address important business and workforce needs, that HRD has lost touch with firsthand knowledge of work and the workplace, and other criticisms and challenges. Literature on dilemmas, challenges, and criticisms of HRD was also reviewed to gain a balanced perspective of the field.

We explore the opportunities and challenges faced by HRD by reviewing the literature to examine what HRD is doing, and what it should be doing, to meet the needs of those it is intended to serve in today's rapidly changing environment. We use the term $H R D$ to refer to the profession as defined by Watkins (1989) and McLean and McLean (2001) and to HRD professionals as those who consider themselves to be members of the HRD profession, whether they identify themselves as researchers/scholars, practitioners, or scholar-practitioners. When the implications of an argument or a section of the article apply only to practitioners (or only to researchers or scholar-practitioners), this will be specifically stated. The review and critique in this article address HRD and, although situated in organizations where boundaries among functional roles and disciplines are frequently blurred, it does not focus on others outside of HRD including executives, operational managers, line workers, and other non-HRD personnel. 
As indicated by its title, this article distinguishes between two perspectives on HRD-what HRD is doing, and what HRD should be doing. We will demonstrate that this distinction points to a discrepancy that is the basis for our premise that change is needed in HRD-the transformation of HRD. After presenting the research questions and methods used for the article, we discuss the factors driving change in HRD. This is followed by a discussion of the dilemmas, challenges, and criticisms of HRD and the implications for change in HRD. The article concludes with discussions of the implications of the article for further research and practice in HRD.

\section{Research Questions}

1. What factors have influenced the evolution of HRD since its origin in the post- World War II period?

2. How has HRD responded to these factors and changes in its environment?

3. What dilemmas, challenges, and criticisms exist of how well HRD meets the needs of those it is intended to serve?

4. What are the implications of these dilemmas, challenges, and criticisms for change in HRD (the transformation of HRD)?

5. What are the implications of the study for further research in HRD? For HRD practice?

\section{Method}

This problem is addressed by providing an integrative review of the literature related to this topic. The integrative literature review is a form of research that reviews, critiques, and synthesizes representative literature on a topic in an integrated way such that new frameworks and perspectives on the topic are generated (Torraco, 2016; Webster \& Watson, 2002). This methodology was chosen because it is particularly effective when existing research is scattered across disparate areas and has not been systematically analyzed and integrated. Such is the case with the literature on the adaptations and advances in 
HRD, the dilemmas, challenges, and criticisms of HRD, and on change and the transformation of HRD. Literature in these areas was reviewed and synthesized into a framework that offers an integrated perspective on the topic.

Two bodies of literature provide the basis for this article-literature on the adaptations and advances in HRD and literature on the dilemmas, challenges, and criticisms of HRD. Literature on adaptations and advances in HRD was reviewed to examine how HRD has adapted to changes in its environment. Literature on dilemmas, challenges, and criticisms of HRD was reviewed to examine how well HRD meets the needs of those it is intended to serve. Juxtaposed with the literature on the adaptations and advances in HRD, this literature was reviewed to provide a balanced view of the field's strengths and limitations. Because the literature reviewed presents Western perspectives and addresses contemporary Western HRD practices, this work does not represent HRD worldwide. The methods for selecting and reviewing the literature in these areas are described next.

Literature on the Adaptations and Advances in HRD

Literature for this category was selected for review only if it met the following criteria:

1. Literature on the adaptations and advances in HRD was selected from the domain of literature that includes HRD, training and development, learning and development, organization development, leadership and management development, coaching and mentoring, career development, and vocational education and training. Literature on human resources and human resource management was selected only if the source of literature explicitly included within its coverage HRD and/or any of the other areas of learning and development listed above in this criterion. Literature that only addressed areas of human resources and human resource management unrelated to HRD (e.g., compensation and benefits) was excluded from the review.

2. Recency of adaptations and advances in HRD-Several adaptations and advances in HRD have occurred through innovations in technology based learning and changes in the 
way work is organized and accomplished. Because the halflife of knowledge in technology and new forms of work is of limited duration, only recent literature on adaptations and advances in HRD (i.e., published within the last 10 years) was selected for review.

3. Literature on the adaptations and advances in HRD was selected from across the research-practice continuum of professional orientation whether written by researchers/ scholars, practitioners, or scholar-practitioners.

Literature on the Dilemmas, Challenges, and Criticisms of HRD

Literature for this category was selected for review only if it was written by authors who do not identify themselves as HRD researchers. This literature selection criterion was used so that the sources of literature on the dilemmas, challenges, and criticisms of HRD would come from outside the field of HRD and from those other than HRD researchers. We intentionally excluded literature about HRD written by HRD researchers and scholar-practitioners as we sought the critical perspectives of those who HRD is intended to serve. This literature came from sources such as independent research centers, federal agencies, business and management journals, and research and technical reports that provide analysis and critique supported by empirical evidence or citations of other research.

\section{Literature Search and Review}

The literature search, review, analysis, and synthesis discussed here are consistent with the procedures for conducting an integrative review of the literature (Torraco, 2016). First, a search was conducted to identify literature on the categories of literature discussed above. Literature was searched in four databases (ERIC, Academic Search Premier, Business Source Complete, and Google Scholar) and 10 academic journals (Advances in Developing Human Resources, Human Resource Development Quarterly, Human Resource Development Review, Human Resource Development International, International Journal of Training and Development, New Horizons in Adult Education and Human Resource Development, Journal of Workplace Learning, Academy of Management Learning and Education, Human Resource Management, 
and European Journal of Training and Development). Key subject terms were used to identify relevant literature in the databases and journals. Literature on the adaptations and advances in HRD was identified using 62 key subject terms, and literature on the dilemmas, challenges, and criticisms of HRD was identified using 42 key subject terms. The search for literature in both areas required using a total of 104 terms.

These key subject terms were used to search the 10 academic journals listed above in addition to the subject descriptors provided by the four databases because a majority of the 104 key subject terms are not listed as descriptors in the databases. For example, 79 of the 104 key subject terms are not listed as subject terms in the Academic Search Premier thesaurus, 92 of the 104 key subject terms are not listed as descriptors in the ERIC thesaurus, and 68 of the 104 key subject terms are not listed as Business Source Complete descriptors. A list of the databases, 10 academic journals, and key subject terms used to search the literature is available from the authors upon request. As pieces of literature were examined in each database and journal, a staged review was conducted (i.e., abstracts, then main body of each literature source) to determine their suitability for selection, with more than half of the literature discarded because they did not meet the criteria for the two categories of literature described above. Those selected for the review, 113 pieces of literature, were examined in detail, included in this integrative literature review, and listed as references at the end of the article.

The next stage of the review examined the literature selected for analysis from the literature search. Critical analysis of the literature deconstructed pieces of literature into their basic elements. The strengths and weakness of each piece of literature were examined, which led to eliminating literature from the review because, although a piece of literature was identified using the key subject terms and deemed relevant during the initial staged review, the literature did not address the literature categories and criteria above. For example, the key words search and initial staged review yielded literature on a broad set of human resource trends and best practices (Ulrich, Allen, Brockbank, Younger, \& Nyman, 2009), but because it did not explicitly include within its coverage HRD or any of the other areas of learning and development listed in the criterion above, it was excluded from the review. Critical analysis of each piece of literature selected 
provided a new, integrated perspective on the topic through synthesis. A form of synthesis was used to bring together related streams of knowledge from the major categories of literature into a significant, value-added contribution to new knowledge. The product of this synthesis is found at the end of the article in Table 1, Dilemmas, Challenges, and Criticisms of HRD and the Implications for Change (the Transformation of $H R D$ ). This table shows the relationships among the related streams of literature discussed above. This is consistent with the purpose of the article-to examine this issue in an integrated way, leading to better understanding of the topic.

We begin by examining factors that drive change and shape the future of the profession. This is followed by a discussion of the adaptations and advances HRD has made in response to changes in its environment, as well as the dilemmas, challenges, and criticisms HRD faces. The article concludes with implications for further research and practice in HRD.

\section{Factors Shaping the Future of HRD}

Several factors drive change and shape the future of HRD including the effects of technology, economics and financial considerations, globalization, equality of opportunity, and the changing nature and organization of work. HRD has made advancements and adaptations in response to these factors. As these factors drive change and shape the future, not only of HRD, but also of the workplace, communities, social and commercial transactions, and global networks, they both influence and transcend HRD. As discussed next, there is abundant research emphasizing the importance of each of these five factors to support their selection for this article.

Technology has the potential to transform work, organizations, and the global economy (Manyika et al., 2013). Scholars who study work, employment, and society have documented examples of technology's effects on how work is performed (Autor, Levy, \& Murname, 2003; Manyika et al., 2016), on those who develop new technologies (Bergvall-Kåreborn \& Howcroft, 2013), and on the training workers rely on to stay abreast of rapidly changing skill requirements (Bell \& Kozlowski, 2007). 
Economics, financial considerations, and constrained budgets have driven change across industry and the economy. Although most organizations are reluctant to acknowledge its importance, cost is a primary consideration when replacing people with automated equipment (Korn Ferry, 2016). Economic constraints and pressure to reduce costs contribute to "technological unemployment"-replacing workers with machines (Brynjolfsson \& McAfee, 2014) and underlie the trend of employer investments in training lagging behind rapidly changing skill requirements (Cappelli, 2012; Carnevale, Smith, \& Strohl, 2013).

Globalization has transformed most organizations and business transactions which now operate on an international scale. It is difficult to underestimate the impact globalization has had on organizations, the workforce, and the economy; globalization is credited with changing organizational strategy (Schwab, 2016), labor markets (Autor, 2010), working conditions (Kalleberg, 2013), and the acquisition and development of human capital (Schwartz, Collins, Stockton, Wagner, \& Walsh, 2017).

Equality of opportunity and diversity are more important than ever in organizations. The emphasis on equality of opportunity, diversity, and inclusiveness is justified not only because it brings in better, brighter talent, but it also improves business outcomes (Kaplan \& Donovan, 2013).

The changing nature and organization of work has been identified as a critical driver of social and economic transformation by the World Bank, a leading international financial institution that provides loans to countries worldwide for major capital and infrastructure improvements (World Bank, 2019). The changing nature of work has led to new network structures for organizing work such as the platform economy (Zysman \& Kenney, 2015), to the growth of alternative employment relationships including independent contractors, on-demand workers, and others in nontraditional job arrangements (Bureau of Labor Statistics, 2018), and to social and economic consequences of the growth of these new work structures, both intended and unintended, for workers (Dokko, Mumford, \& Schannzenbach, 2015) and consumers (Owyang, 2014). 


\section{Adaptations and Advances in HRD}

HRD has adapted to, and taken advantage of, the opportunities presented by technology, economics and financial considerations, globalization, the need for diversity, inclusiveness, and opportunity in the workplace, and the changing nature and organization of work. The advancements and adaptations HRD has made in each of these five areas are discussed next.

\section{Technology}

The evolution of HRD shown in Table 1 continues especially in the area of technology. Learning technologies effecting change in HRD include learning apps for mobile use, content archiving, and program and video distribution to users anytime, anyplace. Technology-based learning and development continues to displace instructor-led classroom training, which declined from $59.43 \%$ of total learning hours used by organizations in 2011 to $51.16 \%$ in 2016 in Association for Talent Development's (ATD) annual survey. Nearly all systematic approaches to training are derived from the generic ADDIE model (analyze, design, develop, implement, and evaluate) that evolved in the post-World War II period (Allen, 2006). Yet, traditional classroom training is gradually being replaced by e-learning, mobile learning, and micro-learning delivered online via phones and tablets, which allows self-paced use (ATD, 2017). Technology-related research in HRD has modeled the relationship between employees' reliance on technology and their job embeddedness and engagement (Charlier, Guay, \& Zimmerman, 2016) and has examined the strategies used by online instructors to engage learners in distance learning (Arghode, Brieger, \& Wang, 2018). HRD researchers also have explored the application of the entertainment and games movement to computer-based training (Bedwell \& Sala, 2010) and the value of Web 2.0 interactive technologies for workplace learning (London \& Hall, 2011). The proliferation of social media has led to HRD research on the value of social media to enhance employee collaboration and knowledge sharing (Thomas \& Akdere, 2013) and to promote democratic participation (Feldman, 2015).

The replacement of face-to-face methods with technology-based tools also continues in organization development. Survey feedback 
requires the systematic collection and analysis of data on attitudes and perceptions across the organization for the purpose of organizational assessment and diagnosis. Formerly manual and time-intensive processes, data collection, analysis, and feedback in organization development are now predominantly conducted via web-based forums and pulse surveys (i.e., short, topic-specific surveys) that make surveys more accessible to employees and reduce the turnaround time from survey administration to action planning (Church, Gilbert, Oliver, Paquet, \& Surface, 2002). Other examples of HRD advances in technology are 36o-degree performance assessment and feedback using customized apps (Cappelli \& Tavis, 2018), augmented reality systems for learning skills in contexts where they can be applied (Porter \& Heppelmann, 2017), the role of technology and virtual HRD in 24/7 work environments (Thomas, 2014), using cost-effective three-dimensional (3D) virtual training environments (Short, 2013), training nanotechnology workers (Yawson, 2010; Yawson \& Greiman, 2016), and computer-generated employee profiles to recommend training and future jobs for employees (Burrell, 2018). Technology is continuing to have a profound effect on the transformation of learning and development and those who manage it.

\section{Economics and Financial Considerations}

Economics and cost reduction also have driven change in HRD. Although most organizations are reluctant to acknowledge its importance, cost is a primary consideration when replacing people with technology-mediated systems (Korn Ferry, 2016). Because labor costs (i.e., payroll and costs associated with hiring, personnel development, and termination) are typically among the highest business expenses, when substitution between labor and capital is possible, a financial perspective alone generally favors investment in physical capital over labor, that is, equipment and technology over workers. The prevailing rationale in U.S. business and industry is that while the initial investment in digital platforms and networks is high, the cost savings from reducing labor-intensive tasks provide a long-term return on the investment (Katz \& Margo, 2014).

Financial concerns and efforts to reduce costs in organizations have compelled all functional areas including HRD to demonstrate their value and justify their costs. To address this expectation, HRD has 
developed methods to evaluate its effectiveness (Russ-Eft \& Preskill, 2001); analyze its costs and benefits (Swanson \& Holton, 1999); demonstrate its ROI (Phillips \& Phillips, 2016); measure the outcomes of virtual HRD (Chapman \& Stone, 2010); show the relationships among HRD, evaluation, and sustainability (Russ-Eft, 2014); and apply measures and indicators to manifestations of work performance (Star, Russ-Eft, Braverman, \& Levine, 2016).

Due in part to financial concerns, HRD now offers fewer labor-intensive, instructor-led training programs which results in L\&D at a lower cost per offering (ATD, 2017). These initiatives demonstrate HRD's responsiveness to the economic forces driving change in the field.

\section{Globalization}

The economic and business dimensions of globalization have integrated what were once separate national economies into a worldwide network of business and financial transactions (Lechner \& Boli, 2014). Globalization enables the disaggregation of work, that is, breaking down a complex work project progressively into components and tasks. This allows allocation of components to alternative production sources based on cost, time, and quality criteria (Manyika et al., 2011). Consequently, organizations like Motorola can design cellular devices in Chicago, make components in Japan and Mexico, and assemble finished products in China, cheaper and faster than it could in the United States alone. Multiphase transactions in banking and insurance show that disaggregated work is not limited to manufacturing-a proposed business investment can be drafted by a group in New York, submitted to a committee for audit and revision in London, and then approved by representatives in several international sites using videoconferencing technology. Through virtual collaboration, people can work together on a project regardless of time or location, enabling work to be accomplished anytime, anywhere.

HRD's response to globalization includes calling for international HRD research and practice to support the United Nation's 2030 sustainable development goals (Zarestky \& Collins, 2017) and a proposal to create sustainable connections around the globe between the environment and society (Scully-Russ \& Cseh, 2015). HRD researchers examined the relative importance of managerial competencies in 22 countries around the globe to assess the specificity of competencies 
for management development in different locations around the world (Clark et al., 2016). Research also has identified that global expansion by organizations does not necessarily increase employee productivity and employment growth (Ataullah, Le, \& Sahota, 2014). Effective teamwork and collaboration across borders and time zones are necessary to conduct business on a global scale (Schwartz et al., 2017). To be effective in a global environment, organizations rely on virtual HRD (McWhorter, 2010), virtual communities of practice (Ardichvili, 2008), and virtual teams and team learning (Widmann, Messmann, \& Mulder, 2016). This research has enabled organizations to capitalize on the opportunities afforded by globalization.

\section{Equality of Opportunity, Diversity, and Inclusiveness}

Promoting opportunity, diversity, and inclusiveness in work opportunities is a prominent feature of the ideology and human relations practices of an increasing number of organizations (Kaplan \& Donovan, 2013). Opportunity, diversity, and inclusiveness are also important factors driving change in the workplace and shaping the future of HRD (Bourke, Garr, van Berkel, \& Wong, 2017).

Advocating workplace opportunity and inclusiveness, HRD researchers have examined workplace contextual supports for lesbian, gay, bisexual, and transgender (LGBT) employees (Webster, Adams, Maranto, Sawyer, \& Thoroughgood, 2018), explored concerns associated with global travel and mobility for LGBT workers (Gedro, Mizzi, Rocco, \& van Loo, 2013), and identified sources of resistance to diversity and developed a framework that shows how this resistance can be reduced (Wiggins-Romesburg \& Githens, 2018). HRD researchers also have emphasized the importance of critical HRD and advocated for research on diversity, inclusiveness, gender differences, spirituality, feminist leadership, sexual orientation, and transformational leadership (Baek \& Kim, 2017; Rocco, Munn, \& Collins, 2018). HRD research has examined veterans and their transitions from military to civilian careers (Minnis, 2017), explored the use of triple-loop learning to manage diversity (Kwon \& Nicolaides, 2017), proposed diversity education as a means of advocating for inclusiveness and diversity (Hite \& McDonald, 2010), delineated the research-to-practice gap in women's career equality (Kossek \& Buzzanell, 2018), identified disability as a form of diversity to be addressed by HRD (Nafukho, Roessler, \& 
Kacirek, 2010), and demonstrated that opportunity, diversity, and inclusive employment practices are beneficial for both workers and organizations (Bourke et al., 2017).

\section{The Changing Nature and Organization of Work}

The way work is organized and accomplished continues to change. Alterations in the composition and availability of jobs (i.e., technological unemployment, the polarization of job opportunities, the growth of knowledge work) have had a dramatic influence on employment, the workforce, and on HRD (Scully-Russ, 2016). As the prevalence of knowledge work has increased, it has triggered the examination of how it differs from work that is more concrete and observable (Arthur, Defillippi, \& Lindsay, 2008). HRD researchers have examined the distinction between knowledge work and other types of work (Jacobs, 2017) and have identified the competencies needed to perform knowledge work (Jacobs, 2017; Swanson, 2007). HRD researchers have identified new intervention strategies that account for both changes in workforce demographics and in the nature of careers (Lyons, Ng, \& Schweitzer, 2014). HRD research also has examined ways to develop the workforce skills needed to keep pace with advances in technology (Yawson, 2010; Yawson \& Greiman, 2016), to promote career pathways and other opportunities for 21st century workforce development (Scully-Russ, 2013), and to balance the need for individual employment security and the organization's desire for flexibility (Kornelakis, 2014).

A different way of looking at learning in the changing workplace is to consider the concept of learning paths (Poell \& van der Krogt, 2010, 2017) and self-directed learning (Ellinger, 2004). A learning path describes "a set of learning activities that are both coherent as a whole and meaningful to the employee" (Poell \& van der Krogt, 2010, p. 217). Learning paths research has identified a shift in emphasis away from formal HRD and the HRD practitioner (Poell, 2017) toward more reliance on employee reflection, self-direction, and experience-based learning (Poell et al., 2018).

So far, we have discussed HRD's responsiveness to changes in technology, economic and financial considerations, globalization, equality of opportunity, and the changing nature of work. The literature reviewed to this point indicates that HRD has adapted to these changes 
and is capable of meeting the evolving needs of those it is intended to serve. HRD has built an extensive record of innovative research and practice over the years that continues today in work that emphasizes evidence-based HRD (Gubbins, Harney, van der Werff, \& Rousseau, 2018) and new models for conducting theoretical literature reviews (Turner, Baker, \& Kellner, 2018) and for creating sustainable careers in today's rapidly changing work environment (McDonald \& Hite, 2018). Although HRD's adaptations and responses to the forces driving change have been effective, there have also been some challenges and criticisms of the field, and these should also be reflected in this article. Consequently, for a balanced perspective on the field, we also sought views on the dilemmas, challenges, and criticisms of HRD as seen by those outside the field of HRD. This does not include literature about HRD written by HRD researchers and scholar-practitioners as we sought the critical perspectives of others and those who HRD is intended to serve, and not those in HRD whose perception of their own profession is necessarily biased. The dilemmas, challenges, and criticism of HRD are discussed next.

\section{Dilemmas, Challenges, and Criticisms of HRD}

Some of the criticisms of HRD and challenges it faces are not new. HRD has been criticized for decades for programs that are peripheral to strategic goals and poorly aligned with business needs (Catalanello \& Redding, 1989; Robinson \& Robinson, 1995). Recent criticisms of HRD include not providing the needs analysis and professional oversight needed to match employee learning needs with the proliferation of online L\&D programs (Schwartz, van Berkel, Hodson, \& Otten, 2014). These and other dilemmas, challenges, and criticism of HRD are discussed next.

\section{Lacking Strategic Alignment}

A perennial criticism of HRD is that it is not aligned with the organization's strategy and business needs. Early critics of the lack of alignment between HRD and strategy identified an obvious reason for this problem-HRD is not an active participant in the business planning process (Catalanello \& Redding, 1989). Rather than passive 
acceptance of a plan for the organization's future developed by a small group of management elite, the authors admonished HRD not only to develop the employee expertise needed to execute strategy but also to actively participate in the development of the strategy itself. Despite the centrality of strategic alignment for organizational success, HRD continues to be criticized for offering programs that are peripheral to strategic goals (Cappelli, 2015), that lack a performance orientation (Robinson \& Robinson, 2008), and that, rather than enable employee expertise, represent the laws, regulations, and human resource practices that constrain workforce utilization and business growth (Hammonds, 2005). Lawler and Boudreau (2015) found that there has been little change over the past 20 years in how human resources including HRD allocate its time. It continues to address administrative, compliance, and traditional bureaucratic activities even though, according to the authors, the main emphases today should be business strategy, organization design, organization development, and the employee skills needed for organizational success and sustainability. Of greatest concern, this criticism is coming from those who HRD is intended to support. As Cappelli and Tavis (2018) stated,

HR has not had to change in recent decades nearly as much as have the line operations it supports. But now the pressure is on, and it's coming from the operating level, which makes it much harder to cling to old talent practices. (p. 52)

Failing to Demonstrate Effectiveness and ROI

Despite having the means to do so, HRD has been criticized for not demonstrating its effectiveness and ROI (Cascio \& Boudreau, 2008) and for failing to use data to support decisions about investments in education, training, and HR-related investments (Cappelli, 2017). The few studies of HRD that have attempted to demonstrate its ROI yielded inconclusive results on whether its costs were justified by its returns (Chochard \& Davoine, 2011; Percival, Cozzarin, \& Formaneck, 2013). Organizations that are dubious about the merits of spending time and resources on employee training make decisions about learning and development primarily based on costs. But because the benefits of HRD are long-term, manifested in skills that are difficult to measure, and less tangible than costs (Torraco, 2009), this inevitably 
results in underinvestment in HRD. And without evidence to the contrary, criticism is directed to HRD.

\section{Focusing on Marginal Programs}

HRD has long been criticized for its preoccupation with offering programs on generational differences, sexual harassment and discrimination, employee wellness, and other topics with little or no impact on business and performance outcomes. For example, while generational differences undoubtedly exist among millennials, generation $\mathrm{X}$, generation $\mathrm{Y}$, baby boomers, and traditionalists, these differences have modest effects on employee engagement (Lyons \& Kuron, 2014; Myers \& Sadaghiani, 2010) and little influence on workplace productivity (Deal, Altman, \& Rogelberg, 2010; Mwangi, 2014). Nonetheless, HRD continues to support such programs. Another topic of HRD research, curiosity, seems to be a reasonable subject for inquiry as the capability to conduct research relies, in part, on one's inquisitiveness and curiosity (Guo, Zhang, \& Zhai, 2010; Reio, 2019). Rather than studying curiosity for its own sake devoid of a work-related context, Reio and Wiswell (200o) demonstrated the relationship between state and trait curiosity and socialization-related learning and, using the self-perceptions of participants, the relationship between curiosity and interpersonal and technical skill knowledge. Training continues to be offered on the damaging effects of sexual harassment and discrimination (Walsh, Bauerle, \& Magley, 2013) as though adults in the workplace are unaware of their harm. Providing training implies that employees lack knowledge and are unaware of the damaging effects of harassment and discrimination (Perry, Kulik, \& Bustamante, 2012). So, when these problems persist after training occurs, HRD is blamed even though top leaders have abdicated responsibility using training instead of enforcing meaningful sanctions against perpetrators of sexual harassment and discrimination. This is an example of the common practice of leaders shifting the burden to others using training instead of assuming accountability themselves. And finally, programs on the benefits of employee wellness seem to assume that people need formal training to appreciate the advantages of wellness over illness. How can HRD be preoccupied with these marginal programs in the face of so many pressing challenges in today's competitive business environment? 


\section{Providing Content Without Needs Analysis}

Content for learning is expanding in variety and accessibility as it moves to the cloud. Recent improvements have been made to methods for conducting needs assessments (ATD, 2018). However, recent growth in accessible content for learning has not been accompanied by rationale for determining what content is actually needed, by whom, how it should be delivered, and whether or not it is effective in meeting the need for learning identified in the first place (Benson-Armer, Gast, \& van Dam, 2016). In fact, the proliferation of online content, without the needs analysis that links each content area to a corresponding learning need, inevitably makes decision-making more difficult (Schwartz et al., 2014). Cappelli and Tavis (2018) provide an appropriate analogy: "Although helpful for those who have clearly defined needs, this is a bit like giving a student a key to the library and telling her to figure out what she must know and then learn it" (p. 52 ). When this plethora of content is made available for adoption by workers without HRD's professional oversight, HRD is justifiably criticized for side-stepping its responsibility for matching L\&D with employee learning needs.

\section{Bringing in Insufficient Firsthand Knowledge of Work and the Workplace}

The origins of work-based learning are grounded in deep, firsthand knowledge of the work itself. The HRD profession grew out of post-World War II applications of the Training Within Industry report (Dooley, 1945) and other studies that first analyzed work and task performance as job productivity could not be improved through training until the job and task requirements of workers were understood (Barley \& Orr, 1997; Gilbert, 1978). However, firsthand knowledge of work has diminished in importance to workplace educators and HRD professionals (Luff, Hindmarsh, \& Heath, 2000). Today, HRD researchers distance themselves from a detailed understanding of the work itself, as evidenced by the lack of recent research on the topic. Analyzing work and developing an intimate knowledge of the workplace are necessary if theory, research, and practice are to keep pace with the changing dynamics of work and occupations (Barley \& Kunda, 2001; National Research Council, 1999). There may be diminished interest 
among HRD scholars in observing in the workplace to assess the work itself and the work activities of employees, supervisors, and others to develop training and other HRD interventions. As HRD becomes further removed from its work-based origins, how can HRD professionals take advantage of the developmental opportunities of work experience if they are unaware of what the work itself entails?

Although HRD has adapted to factors driving change in the field, it has also been criticized in each of the areas discussed above. The implications of these criticisms of HRD for change in the field (i.e., the transformation of HRD) are discussed next.

\section{Discussion}

\section{Implications for Transforming $H R D$}

The claims we make about what HRD is doing, and should be doing, are our assessments and interpretation of the literature as it exists today. The integrative literature review was used because it is effective when existing research is scattered across disparate areas and has not been systematically analyzed and integrated as is the case with the literature on the adaptations and advances in HRD, the dilemmas, challenges, and criticisms of HRD, and on change and the transformation of HRD. This literature review is the first phase of our research and is a necessary prerequisite to an upcoming phase of empirical research we plan to conduct, which we expect to confirm (or disconfirm) our judgments.

Literature on the dilemmas, challenges, and criticisms of HRD and the implication for change in HRD has been integrated into a significant, value-added contribution to new knowledge. The product of this synthesis is given in Table 1. Dilemmas, Challenges, and Criticisms of $H R D$ and the Implications for Change (the Transformation of HRD) show the relationships among the related streams of literature. Successful change depends on HRD developing the characteristics and capabilities shown in the right-hand column of Table 1 (Implications for Change). In light of the need for change and in the spirit of continuous improvement, HRD is encouraged to transform itself, or risk being sidelined. 


\section{Implications for Further Research in HRD}

The implications of the issues summarized in Table 1 for further research in HRD are discussed next.

The transformation of HRD-What is the need? This article distinguishes between two perspectives on HRD-what HRD is doing and what HRD should be doing. This distinction points to a discrepancy that is the basis for our premise that change is needed in HRD-the transformation of HRD. However, more research is needed to explore the role of HRD in today's work environment and, indeed, whether or not HRD is even needed today! As an integrative review of the literature, this article is necessarily a first step toward identifying the need for change in HRD. Further research, which could most suitably be done in the form of an empirical study, might examine the perceptions of leaders, supervisors, and other stakeholders in HRD about how well HRD is meeting the needs of those it is intended to serve. Differences might exist between stakeholders in large versus small organizations, as well as for practitioners operating in different Western countries. By employing a qualitative research design that uses semi-structured interviews the following questions could be explored in depth: How can HRD be more effective? What is the role of HRD in an environment in which managers and others in supervisory roles are increasingly responsible for promoting learning and development? These questions about change in HRD warrant further research, most likely in the form of an interview-based qualitative study with participants from different geographies and different organizational contexts.

Learning content: Who is responsible? The proliferation of online learning content has not been accompanied by the delineation of HRD's role when content can be accessed directly by employees. When content is made available for adoption by employees without HRD's professional oversight, HRD is justifiably criticized for side-stepping its responsibility for matching L\&D with employee learning needs. More research is needed on HRD's role when learning content can be accessed directly by employees, bypassing traditional modes of content delivery by HRD.

The issue of learning content without needs analysis goes beyond HRD's responsibility for content curation. Content curation is the 
process of analyzing and categorizing weband enterprise-based learning content and presenting it to users in an organized and meaningful way (Dale, 2014). The problem of learning content without needs analysis occurs after the curation of content and delivery method. What assurances exist that appropriate content is being accessed and used effectively by employees? Is HRD expected to monitor the use of online learning content to assure that it is used effectively? Or should HRD play a more passive standby role and act only when requested to do so? More research, possibly in the form of a quantitative survey study, is needed to delineate the appropriate role for HRD as access to online content continues to expand. This study could be built on an existing survey instrument and could lend itself to be conducted transnationally. However, as discussed next, learning paths may be a direction for more effective HRD practice.

\section{Implications for HRD Practice}

The implications of the issues summarized in Table 1 for HRD practice are discussed next.

Learning paths: Support self-directed employees. Learning paths shift the emphasis away from formal HRD and the HRD practitioner toward more reliance on employee reflection, self-direction, and experience-based learning. The employee chooses the learning path, making a conscious effort to learn and expand as his or her job role changes and expands (Poell, 2017). However, despite greater reliance on employee autonomy and self-direction in today's workplace, traditional HRD programs persist in which employees are passive recipients of interventions that are predefined by HRD professionals. A shift away from this outdated approach is needed in HRD practice with greater emphasis placed on employee self-direction and learning paths (Poell et al., 2018).

Adopt a business partner mind-set. If HRD is to become indispensable to organizations and those it is intended to serve, it must adopt a business partner mind-set and support on-demand learning and development in areas critical for the organization's success. In the vignette at the beginning of the article, Natasha's boss, the vice president of product development, acknowledges the importance of Natasha's 
leadership competency model for the company's new growth strategy, illustrating that her role is considered vital to business success. But how can HRD facilitate the development of the skills employees need for the future if it does not understand how the business is expected to grow in the future?

This capability requires HRD personnel to acquire a solid understanding of the operations and dynamics of the business and a voice in strategic decision-making so they can contribute directly to business growth and development by aligning employee expertise with strategic goals.

Given today's hypercompetitive business environment, HRD is at a critical juncture in its development. It must decide between being a valued business partner or offering programs that are peripheral to organizational needs and devoid of work-related contexts. Earlier in the article examples of marginal programs were cited, some of which are offered at the expense of those that address important business and workforce needs. An HRD function that is sidetracked by offering marginal programs is less likely to be perceived by key decision makers as critical for the organization's success and more likely to be sidelined, bypassed, or eliminated. In short, HRD professionals are encouraged to adopt a business partner mind-set by prioritizing programs and by promoting employee learning and development in ways that promote the overall growth of the business. HRD is encouraged to embrace these criticisms, take advantage of the opportunity for change and self-improvement, or risk being sidelined.

Bring in firsthand knowledge of work and the workplace. Zuboff's (1988) book, In the Age of the Smart Machine: The Future of Work and Power, fundamentally changed the way we think about the nature and organization of work. Zuboff's work traced the emergence of the information age in organizations and is widely considered the definitive study of how information technology has transformed the workplace (Burton-Jones, 2014). Zuboff accomplished this, not through secondhand accounts of developments in the workplace, but through in-depth, firsthand exposure to actual work practices in office, factory, executive, technical, and craft workplaces. Other seminal studies such as the Hawthorne experiments (Roethlisberger \& Dickson, 1939), the Center for Creative Leadership's acclaimed demonstration of the developmental value of work experience and challenging job assignments 
(McCall, 1998; McCall, Lombardo, \& Morrison, 1988), and Hackman and Oldham's (1980) foundational studies on work redesign, could not have been accomplished without the researchers' direct, firsthand exposure to work activities and intimate knowledge of the workplace.

HRD considers itself on the forefront of work-based learning. But seminal work in this area is unlikely to come from HRD researchers if they become further removed from direct, firsthand knowledge of work and the workplace. Consequently, we acknowledge the postWorld War II roots of HRD in job training and work-based learning and we encourage renewed interest in, and firsthand knowledge of, the work itself, its origins, and engagement in workplace studies as the basis for authentic work-based learning. Natasha's reliance on her firsthand knowledge of the company's technology-based products and workplace for the management of change projects illustrates the value of this capability.

Strategic alignment and ROI: Implement what we already know. HRD's struggle to align programs with organizational strategy and workforce needs is long-standing and well documented (Cappelli, 2015; Catalanello \& Redding, 1989; Hammonds, 2005; Lawler \& Boudreau, 2015; Robinson \& Robinson, 1995). Similarly, HRD continues to be implicated for not adequately demonstrating its effectiveness and ROI despite having developed the means to do so (Cascio \& Boudreau, 2008). Because Natasha recognizes the importance of demonstrating the effectiveness of learning and development, she developed a narrative that supports the ROI numbers for the company's global leadership development program. Lack of strategic alignment and not adequately demonstrating its effectiveness are two areas in which the emphasis should be on action, not further study. The knowledge base already exists to align HRD with strategy (Torraco \& Swanson, 1995) and to demonstrate its effectiveness (Chapman \& Stone, 2010; RussEft, 2014; Russ-Eft \& Preskill, 2001). HRD practitioners need to implement what is already known in these areas; HRD researchers need to emphasize the application of research in these areas. Developing employee expertise, demonstrating the effectiveness of HRD, aligning learning and development with organizational strategy, and other HRD responsibilities are all areas with an ample knowledge base. HRD needs to act, not accumulate more studies. 


\section{Conclusion}

In the period since its early development, HRD interventions and strategies have expanded and changed. With more responsibility for learning and development assumed by others, HRD is now at a critical juncture in its development. This article has juxtaposed recent adaptations and advances in HRD with perspectives on the dilemmas, challenges, and criticisms HRD faces to reveal a discrepancy between what HRD is doing, and what HRD should be doing. This points to the need for further research to examine the perceptions of leaders, supervisors, employees, and other stakeholders in HRD about how well HRD is meeting the needs of those it is intended to serve. It also underlines the emphasis in HRD practice on strengthening its alignment with organizational strategy, demonstrating its effectiveness, and prioritizing programs to support the organization's business and workforce development needs. In the spirit of continuous improvement, HRD is encouraged to transform itself, or risk being sidelined.

Conflicting Interests - The authors declared no potential conflicts of interest with respect to the research, authorship, and/or publication of this article.

Funding - The authors received no financial support for the research, authorship, and/or publication of this article.

\section{Author Biographies}

Richard J. Torraco is an associate professor in the Department of Educational Administration at the University of Nebraska - Lincoln. He serves as a faculty member in the educational leadership and community college leadership programs and conducts research and teaching in workforce and human resource development, and in community college leadership.

Henriette Lundgren is the Director of learning and development at Corning, Inc. in Ithaca, New York and a research associate in the Department of Human and Organizational Learning at George Washington University in Washington, DC. 


\section{References}

Allen, W. C. (2006). Overview and evolution of the ADDIE training system. Advances in Developing Human Resources, 8, 430-441. doi:10.1177/1523422306292942

Ardichvili, A. (2008). Learning and knowledge sharing in virtual communities of practice: Motivators, barriers, and enablers. Advances in Developing Human Resources, 10, 541-554. doi:10.1177/1523422308319536

Arghode, V., Brieger, E., \& Wang, J. (2018). Engaging instructor design and instructor role in online learning environment. European Journal of Training and Development, 42, 366-380. doi:10.1108/EJTD-12-2017-0110

Arthur, M. B., Defillippi, R. J., \& Lindsay, V. J. (2008). On being a knowledge worker. Organizational Dynamics, 37, 365-377. doi:10.1002/nha3.20206

Association for Talent Development. (2017). 2017 state of the industry report. Alexandria, VA: Author. Retrieved from https://.td.org/ research-reports/2017-state-of-the-industry

Association for Talent Development. (2018). Needs assessments: Design and execution for success. Alexandria, VA: Author. Retrieved from https://www. td.org/research-reports/needs-assessments

Ataullah, A., Le, H., \& Sahota, A. S. (2014). Employee productivity, employment growth, and the cross-border acquisitions by emerging market firms. Human Resource Management, 53, 987-1004. doi:10.1002/hrm.21619

Autor, D. H. (2010). The polarization of job opportunities in the U.S. labor market: Implications for employment and earnings. Washington, DC: Center for American Progress.

Autor, D. H., Levy, F., \& Murname, R. J. (2003). The skill content of recent technological change: An empirical exploration. The Quarterly Journal of Economics, 116, 1279-1333. doi:10.1162/o03355303322552801

Baek, P., \& Kim, N. (2017). The subjective perceptions of critical HRD scholars on the current state and the future of CHRD. Human Resource Development Quarterly, 28, 135-161. doi:10.1002/hrdq.21275

Barley, S. R., \& Kunda, G. (2001). Bringing work back in. Organization Science, 12, 76-95. doi:10.1287/orsc.12.1.76.10122

Barley, S. R., \& Orr, J. E. (1997). Between craft and science: Technical work in U.S. settings. Ithaca, NY: ILR Press. doi:10.1177/1523422310374974

Bedwell, W. L., \& Sala, E. (2010). Computer-based training: Capitalizing on lessons learned. International Journal of Training and Development, 14, 239249. doi:10.1111/j.14682419.2010.00355.X

Bell, B. S., \& Kozlowski, S. W. J. (2007). Advances in technology-based training [Electronic version]. In S. Werner (Ed.), Managing human resources in North America (pp. 27-43). Abingdon, UK: Routledge.

Benson-Armer, R., Gast, A., \& van Dam, N. (2016). Learning at the speed of business. Mckinsey Quarterly, 19(2), 1-5. Retrieved from https:// www.mckinsey.com/business-functions/organization/our-insights/ learning-at-the-speed-of-business 
Bergvall-Kåreborn, B., \& Howcroft, D. (2013). “The future's bright, the future's mobile": A study of Apple and Google mobile application developers. Work, Employment \& Society, 1-18. doi:10.1177/0950017012474709

Bourke, J., Garr, S., van Berkel, A., \& Wong, J. (2017). Diversity and inclusion: The reality gap. In J. Schwartz, L. Collins, H. Stockton, D. Wagner, \& B. Walsh (Eds.), Rewriting the rules for the digital age: 2017 Deloitte global human capital trends (pp. 107-117). New York, NY: Deloitte University Press. Retrieved from https://www2.deloitte.com/us/en/pages/human-capital/articles/ introduction-human-capital-trends.html

Brynjolfsson, E., \& McAfee, A. (2014). The second machine age: Work, progress, and prosperity in a time of brilliant technologies. New York, NY: W.W. Norton. Retrieved from https:// books.wwnorton.com/books/detail. aspx?id $=4294987234$

Bureau of Labor Statistics. (2018). Contingent and alternative employment arrangements. Washington, DC: U.S. Department of Labor. Retrieved from www.bls.gov/cps/contingent-and-alternative-arrangements-faqs.htm

Burrell, L. (2018). Co-creating the employee experience. Harvard Business Review, 96(2), 54-58.

Burton-Jones, A. (2014). What have we learned from the. Smart Machine? Information and Organization, 24, 71-105. doi:10.1016/j.infoandorg.2014.03.001

Cappelli, P. (2012). Why good people can't get jobs: The skills gap and what companies can do about it. Philadelphia, PA: Wharton Digital Press.

Cappelli, P. (2015). Why we love to hate HR . . . and what HR can do about it. Harvard Business Review, 93(7/8), 54-61.

Cappelli, P. (2017). There's no such thing as big data in HR. Harvard Business Review, 95(3), 27-29.

Cappelli, P., \& Tavis, A. (2018). HR goes agile. Harvard Business Review, 96(2), 46-52.

Carnevale, A. P., Smith, N., \& Strohl, J. (2013). Recovery: Job growth and education requirements through 2020. Washington, DC: Center on Education and the Workforce, Georgetown University. https://cew.georgetown.edu/cew-reports/ recovery-job-growth-and-education-requirements-through-2020/

Cascio, W. F., \& Boudreau, J. W. (2008). Investing in people: Financial impact of human resource initiatives. Upper Saddle River, NJ: Pearson Education.

Catalanello, R., \& Redding, J. (1989). Three strategic training roles. Training and Development Journal, 73(12), 51-54. doi:10.1287/orsc.12.1.76.10122

Chapman, D. D., \& Stone, S. J. (2010). Measurement of outcomes in virtual environments. Advances in Developing Human Resources, 12, 665-68o. doi:10.1177/1523422310394792

Charlier, S. D., Guay, R. P., \& Zimmerman, R. D. (2016). Plugged in or disconnected? A model of the effects of technological factors on employee job embeddedness. Human Resource Management, 55, 109-126. doi:10.1002/ hrm.21716 
Chochard, Y., \& Davoine, E. (2011). Variables influencing the return on investment in management training programs: A utility analysis of 10 Swiss cases. International Journal of Training and Development, 15, 225-243. doi:10.1111/j.1468-2419.2011.00379.x

Church, A. H., Gilbert, M., Oliver, D. H., Paquet, K., \& Surface, C. (2002). The role of technology in organization development and change. Advances in Developing Human Resources, 4, 493-511. doi:10.1177/152342202237525

Clark, J. M., Quast, L. N., Jang, S., Wohkittel, J., Center, B., Edwards, K., \& Bovornusvakool, W. (2016). GLOBE study culture clusters: Can they be found in importance ratings of managerial competencies? European Journal of Training and Development, 40, 534-553. doi:10.1108/EJTD-03-2016-0016

Dale, S. (2014). Content curation: The future of relevance. Business Information Review, 31, 199-205. doi:10.1177/0266382114564267

Deal, J. J., Altman, D. G., \& Rogelberg, S. G. (2010). Millennials at work: What we know and what we need to do (if anything). Journal of Business and Psychology, 25, 191-199. doi:10.1177/1523422310374974

Deloitte. (2016). The future of the workforce: Critical drivers and challenges. New York, NY: Deloitte University Press. Retrieved from https://www2.deloitte. $\mathrm{com} /$... /deloitte-au-hc-future-of-workforce-critical-drivers-challenges.html

Dokko, J., Mumford, M., \& Schannzenbach, D. W. (2015). Workers and the online gig economy: A Hamilton Project framing paper. Washington, DC: The Brookings Institute.

Dooley, C. R. (1945). The training within industry report, 1910-1945. Washington, DC: War Manpower Commission, Bureau of Training, Training Within Industry Service. doi:10.10 80/09585192.1945.556801

Ellinger, A. (2004). The concept of self-directed learning and its implications for human resource development. Advances in Developing Human Resources, 6, 158-177. doi:10.1111/14679310.00163

Feldman, E. M. (2015). The influence of social media on adult learners' knowledge construction and democratic participation. New Horizons in Adult Education and Human Resource Development, 27, 59-65. doi:10.1002/nha3.20123

Gedro, J., Mizzi, R. C., Rocco, T. S., \& van Loo, J. (2013). Going global: Professional mobility and concerns for LGBT workers. Human Resource Development International, 16, 282-297. doi:10.1080/13678868.2013.771869

Gilbert, T. F. (1978). Human competence: Engineering worthy performance. New York, NY: McGraw-Hill. doi:10.1002/hfm.20502

Gubbins, C., Harney, B., van der Werff, L., \& Rousseau, D. (2018). Enhancing the trustworthiness and credibility of human resource development: Evidencebased management to the rescue? Human Resource Development Quarterly, 29, 193-202. doi:10.1002/hrdq.21313

Guo, S., Zhang, G., \& Zhai, R. (2010). A potential way of enquiry into human curiosity. British Journal of Educational Technology, 41, E48-E52. doi:10.1080/09585190802707433

Hackman, J. R., \& Oldham, G. (1980). Work redesign. Reading, MA: AddisonWesley. doi:10.5328/cter39.1.79 
Hammonds, K. E. (2005). Why we hate HR. Fast Company, 97, 40-47.

Hardy, Q. (2016, November 25). The new workplace is agile, and nonstop. Can you keep up? The New York Times. Retrieved from https://www.nytimes. com/2016/11/25/technology/the-new-workplace-is-agile-and-nonstop-canyou-keep-up.html

Hite, L. M., \& McDonald, K. S. (2010). Perspectives on HRD and diversity education. Advances in Developing Human Resources, 12, 283-294. doi:10.1177/1523422310374974

Jacobs, R. L. (2017). Knowledge work and human resource development. Human Resource Development Review, 16, 176-202.

Kalleberg, A. L. (2013). Globalization and precarious work. Contemporary Sociology: A Journal of Reviews, 42, 700-706. doi:10.1177/0094306113499536

Kaplan, M., \& Donovan, M. (2013). The inclusion dividend: Why investing in diversity pays off. Brookline, MA: Bibliomotion. Available from $\underline{\mathrm{http}} / / /$ theinclusiondividend.com/

Katz, L. F., \& Margo, R. A. (2014). Technical change and the relative demand for skilled labor: The United States in historical perspective. In L. P. Boustan, C. Frydman, \& R. A. Margo (Eds.), Human capital in history: The American record (pp. 15-58). Retrieved from http:// press.uchicago.edu/ucp/books/book/ chicago/H/bo18411047.html

Kornelakis, A. (2014). Balancing flexibility with security in organizations? Exploring the links between flexicurity and human resource development. Human Resource Development Review, 13, 398-412.

Korn Ferry. (2016). Korn Ferry global study: Majority of CEOs see more value in technology than in their workforce. Retrieved from https://www.kornferry. com/press/korn-ferry-global-study-majority-of-ceos-see-more-value-intechnology-than-their-workforce/

Kossek, E. E., \& Buzzanell, P. M. (2018). Women's career equality and leadership in organizations: Creating an evidence-based positive change. Human Resource Management, 57, 813-822. doi:10.1002/hrm.21936

Kwon, C., \& Nicolaides, A. (2017). Managing diversity through triple-loop learning: A call for paradigm shift. Human Resource Development Review, 16, 85-99.

Lawler, E. E., \& Boudreau, J. W. (2015). Global trends in human resource management: A twenty-year analysis. Palo Alto, CA: Stanford University Press. Retrieved from https://www.sup.org/books/title/?id=24277

Lechner, F. J., \& Boli, J. (Eds.). (2014). The globalization reader (5th ed.). West Sussex, UK: Wiley-Blackwell. Retrieved from https://www.wiley.com/en-us/ The+Globalization+Reader\%2C+5th+Edition-p-9781118733554

London, M., \& Hall, M. J. (2011). Web 2.0 support for individual, group and organizational learning. Human Resource Development International, 14, 103113. doi:10.1080/136788 68.2011.542902

Luff, P., Hindmarsh, J., \& Heath, C. (Eds.). (2000). Workplace studies: Recovering work practice and informing system design. Cambridge, UK: Cambridge University Press. doi:10.1016/j.indmarman.2000.04.095 
Lyons, S. T., \& Kuron, L. (2014). Generational differences in the workplace: A review of the evidence and directions for future research. Journal of Organizational Behavior, 35, S139-S157. doi:10.1002/job.1913

Lyons, S. T., Ng, E. S., \& Schweitzer, L. (2014). Changing demographics and the shifting nature of careers: Implications for research and human resource development. Human Resource Development Review, 13, 181-206. doi:10.1177/1534484314524201

Manyika, J., Chui, M., Bughin, J., Dobbs, R., Bisson, P., \& Marrs, A. (2013). Disruptive technologies: Advances that will transform life, business, and the global economy. McKinsey Global Institute. Retrieved from http:// www.mckinsey.com/business-functions/digital-mckinsey/our-insights/ disruptive-technologies

Manyika, J., Lund, S., Auguste, B., Mendonca, L., Welsh, T., \& Ramaswamy, S. (2011). An economy that works: Job creation and America's future. Retrieved from www.mckinsey.com

Manyika, J., Lund, S., Bughin, J., Robinson, K., Mischke, J., \& Mahajan, D. (2016). Independent work: Choice, necessity, and the gig economy. McKinsey Global Institute. Retrieved from https:// www.mckinsey.com/global-themes/employment-and-growth/ independent-work-choice-necessity-and-the-gig-economy

McCall, M. W. (1998). High flyers: Developing the next generation of leaders. Boston, MA: Harvard Business School Press.

McCall, M. W., Lombardo, M. M., \& Morrison, A. M. (1988). The lessons of experience: How successful executives develop on the job. New York, NY: Lexington Books.

McDonald, K. S., \& Hite, L. M. (2018). Conceptualizing and creating sustainable careers. Human Resource Development Review, 17, 349-372. doi:10.1177/1534484318796318

McLean, G. N., \& McLean, L. (2001). If we can't define HRD in one country, how can we define it in an international context? Human Resource Development International, 4, 313-326. doi:10.1080/1367886011005933

McWhorter, R. R. (2010). Exploring the emergence of virtual human resource development. Advance in Developing Human Resources, 12, 623-631. doi:10.1177/1523422310395367

Minnis, S. E. (2017). Veterans in career transition and employment. Advances in Developing Human Resources, 19, 3-5. doi:10.1177/1523422316682951

Mwangi, W. J. (2014). The effect of a multi-generational workforce on employee productivity: A case study of Kenya electricity generation company. Nairobi, Kenya: Chandaria School of Business, United States International University.

Myers, K., \& Sadaghiani, K. (2010). Millennials in the workplace: A communication perspective on millennial's organizational relationships and performance. Journal of Business Psychology, 25, 225-238. doi:10.1006/ jbp.2010.1544 
Nafukho, F. M., Roessler, R. T., \& Kacirek, K. (2010). Disability as a diversity factor: Implications for human resource practices. Advances in Developing Human Resources, 12, 395-406. doi:10.1177/1523422310379209

National Research Council. (1999). The changing nature of work: Implications for occupational analysis. Washington, DC: National Academy Press. doi:10.1016/j. indmarman.1999.08.015

Owyang, J. (2014). People are sharing in the collaborative economy for convenience and price. Collaborative Economy. Retrieved from http://www.web-strategist.com/blog/2014/03/24/ people-are-sharing-in-the-collaborative-economy-for-convenience-and-price/

Percival, J. C., Cozzarin, B. P., \& Formaneck, S. D. (2013). Return on investment for workplace training: The Canadian experience. International Journal of Training and Development, 17, 20-32. doi:10.1111/ijtd.12002

Perry, E. L., Kulik, C. T., \& Bustamante, J. (2012). Factors impacting the knowingdoing gap in sexual harassment training. Human Resource Development International, 15, 589-608. Doi :10.1080/13678868.2012.726540

Phillips, J. J., \& Phillips, P. P. (2016). Handbook of training evaluation and measurement methods (4th ed.). London, England: Routledge.

Poell, R. F. (2017). Time to "flip" the training transfer tradition: Employees create learning paths strategically. Human Resource Development Quarterly, 28, 9-15. doi:10.1002/hrdq.21279

Poell, R. F., Lundgren, H., Bang, A., Justice, S. B., Marsick, V. J., Sung, S. Y., \& Yorks, L. (2018). How do employees' individual learning paths differ across occupations? A review of 10 years of empirical research. Journal of Workplace Learning. Retrieved from https:// www.emerald.com/insight/content/ doi/10.1108/JWL-01-2018-0019/full/html

Poell, R. F., \& van der Krogt, F. J. (2010). Individual learning paths of employees in the context of social networks. In S. Billet (Ed.), Learning through practice: Models, traditions, orientations, and approaches (pp. 197-221). Dordrecht, The Netherlands: Springer. doi:10.1016/j.ltpm.2010.10.001

Poell, R. F., \& van der Krogt, F. J. (2017). Why is organizing human resource development so problematic? Perspectives from the learning-network theory (Part I). Learning Organization, 24, 180-193. doi:10.1002/lo.20013

Porter, M. E., \& Heppelmann, J. E. (2017). Why every organization needs an augmented reality strategy. Harvard Business Review, 95(6), 46-57.

Reio, T. G. (2019). Curiosity is welcome here [Editorial]. Human Resource Development Quarterly, 30, 131-132. doi:10.1002/hrdq.21357

Reio, T. G., \& Wiswell, A. (2000). Field investigation of the relationship among adult curiosity, workplace learning, and job performance. Human Resource Development Quarterly, 11, 5-30. doi:10.1002/hrdq.21313

Robinson, D. G., \& Robinson, J. C. (1995). Performance consulting: Moving beyond training. San Francisco, CA: Berrett-Koehler.

Robinson, D. G., \& Robinson, J. C. (2008). Performance consulting: A practical guide for HR and learning professionals (2nd ed.). San Francisco, CA: Berrett-Koehler. 
Rocco, T. R., Munn, S. L., \& Collins, J. C. (2018). The critical turn in human resources development. In M. Milana, S. Webb, S. Holford, R. Waller, \& P. Jarvis (Eds.), The Palgrave international handbook on adult and lifelong education and learning (pp. 227-244). London, England: Palgrave Macmillan. Retrieved from https://www.palgrave.com/gp/book/9781137557827

Roethlisberger, F. J., \& Dickson, W. J. (1939). Management and the worker. Cambridge, MA: Harvard University Press. doi:10.1108/01437729810216694

Russ-Eft, D. F. (2014). Human resource development, evaluation, and sustainability: What are the relationships? Human Resource Development International, 17, 545-559. doi:10.1080/13678868.2014.954190

Russ-Eft, D. F., \& Preskill, H. (2001). Evaluation in organizations: A systematic approach to enhancing learning, performance, and change. Cambridge, MA: Perseus. doi:10.1080/o9 585192.2001.939987

Schwab, K. (2016). The fourth industrial revolution. New York, NY: Crown Business.

Schwartz, J., Collins, L., Stockton, H., Wagner, D., \& Walsh, B. (2017). Rewriting the rules for the digital age: 2017 Deloitte global human capital trends. New York, NY: Deloitte University Press. Retrieved from https://www2.deloitte. com/us/en/pages/human-capital/articles/introduction-human-capital-trends. $\underline{\mathrm{html}}$

Schwartz, J., van Berkel, A., Hodson, T., \& Otten, I. W. (2014). The overwhelmed employee: Simplify the work environment. New York, NY: Deloitte.

Retrieved from https://www2.deloitte.com/insights/us/en/focus/ human-capital-trends/2014/hc-trends-2014-overwhelmed-employee. html?id=gx:el:dc:dup682:cons:a

Scully-Russ, E. (2013). Are green jobs career pathways a path to a 21stcentury workforce development system? Adult Learning, 24, 6-13. doi:10.1177/1523422315600839

Scully-Russ, E. (2016). Taking care of business: The opportunities and dilemmas for adult education in a changing economy. New Directions for Adult and Continuing Education, 149, 73-82. doi:10.1002/ndace.28

Scully-Russ, E., \& Cseh, M. (2015). Green HRD: The greening of society and the implications for human resource development theory and practice. Advances in Developing Human Resources, 17, 411-425. doi:10.1177/1523422315600839

Short, D. C. (2013). Designing a 3-D virtual HRD environment from a scholarpractitioner perspective. Advances in Developing Human Resources, 15, 270283. doi:10.1177/1523422313487838

Star, S., Russ-Eft, D., Braverman, M. T., \& Levine, R. (2016). Performance measurement and performance indicators: A literature review and a proposed model for practical adoption. Human Resource Development Review, 15, 151-181. doi:10.1177/1534484316636220

Swanson, R. A. (2007). Analysis for improving performance: Tools for diagnosing organizations and documenting workplace expertise. San Francisco, CA: BerrettKoehler. doi:10.1177/1534484316673713 
Swanson, R. A., \& Holton, I. I. I. (1999). Results: How to assess performance, learning, and perceptions in organizations. San Francisco, CA: Berrett-Koehler. doi:10.1177/001 979390105400307

Thomas, K. J. (2014). Workplace technology and the creation of boundaries: The role of VHRD in a 24/7 work environment. Advances in Developing Human Resources, 16, 281-295. doi:10.1177/1523422314532092

Thomas, K. J., \& Akdere, M. (2013). Social media as collaborative media in workplace learning. Human Resource Development Review, 12, 329-344.

Torraco, R. J. (2009). Economics, human capital theory, and human resource development. In R. A. Swanson \& E. F. Holton (Eds.), Foundations of human resource development, 2nd Ed. (pp. 120-128). San Francisco, CA: Berrett-Koehler.

Torraco, R. J. (2016). Writing integrative literature reviews: Using the past and present to explore the future. Human Resource Development Review, 15, 404428. doi:10.1177/1534484316671606

Torraco, R. J., \& Swanson R. A. (1995). The strategic roles of human resource development. Human Resource Planning, 18, 10-21. doi:10.1177/1523422310374974

Turner, J. R., Baker, R., \& Kellner, F. (2018). Theoretical literature review: Tracing the life cycle of a theory and its verified and falsified statements. Human Resource Development Review, 17, 34-61. doi:10.1177/1534484317749680

Ulrich, D., Allen, J., Brockbank, W., Younger, J., \& Nyman, M. (2009). HR transformation: Building human resources from the outside in. New York, NY: McGraw-Hill Education.

Walsh, B. M., Bauerle, T. J., \& Magley, V. J. (2013). Individual and contextual inhibitors of sexual harassment training motivation. Human Resource Development Quarterly, 24, 215-237. doi:10.1002/hrdq.21158

Watkins, K. E. (1989). Human resource development. In S. B. Merriam \& P. M. Cunningham, (Eds.), Handbook of adult and continuing education (pp. 24-36). San Francisco, CA: Jossey-Bass.

Webster, J., Adams, G. A., Maranto, C. L., Sawyer, K., \& Thoroughgood, C. (2018). Workplace contextual supports for LGBT employees: A review, meta-analysis, and agenda for future research. Human Resource Management, 57, 193-210. doi:10.1002/hrm.21873

Webster, J., \& Watson, R. T. (2002). Analyzing the past to prepare for the future: Writing a literature review. MIS Quarterly, 26, xiii-xxiii.

Whittaker, S., \& Marchington, M. (2003). Devolving HR responsibility to the line: Threat, opportunity or partnership? Employee Relations, 25, 245-261. doi:10.1108/01425450310475847 Widmann, A., Messmann, G.,

Mulder, R. H. (2016). The impact of team learning behaviors on team innovative work behavior: A systematic review. Human Resource Development Review, 15, 429-458. doi:10.1177/1534484316673713

Wiggins-Romesburg, C. A., \& Githens, R. P. (2018). The psychology of diversity resistance and integration. Human Resource Development Review, 17, 179-198. doi:10.1177/1534484318765843 
World Bank. (2019). The changing nature of work (Work Development Report 2019). Washington, DC: World Bank Group. Retrieved from http://www. worldbank.org/en/publication/wdr2019

Yawson, R. M. (2010). Skill needs and human resource development in the emerging field of nanotechnology. Journal of Vocational Education \& Training, 62, 285-296.

Yawson, R. M., \& Greiman, B. C. (2016). A systems approach to identify skill needs for agrifood nanotechnology: A multiphase mixed methods study. Human Resource Development Quarterly, 27, 517-545. doi:10.1002/hrdq.21266

Zarestky, J., \& Collins, J. C. (2017). Supporting the United Nation's 2030 sustainable development goals: A call for international HRD action. Human Resource Development International, 20, 371-381. doi:10.1080/13678868.2017. 1329370

Zuboff, S. (1988). In the age of the smart machine: The future of work and power. New York, NY: Basic Books.

Zysman, J., \& Kenney, M. (2015). Where will work come from in the era of the cloud and big data? New York, NY: Roosevelt Institute. Retrieved from http:// rooseveltinstitute.org/search/?s=Where+will+work+come+from + in + the + era + of +the+cloud+and+big+data\&=Search 
Table 1. Dilemmas, Challenges, and Criticisms of HRD and the Implications for Change (the Transformation of HRD).

Dilemmas, challenges, and criticisms of HRD

1. Lacking strategic alignment

HRD is criticized for not being aligned with the organization's strategy and for offering programs that lack a performance orientation.
Implications for change (the transformation of HRD)

To create strategic alignment, HRD should

- Contribute directly to strategic business growth and development.

- Develop a deeper understanding of the operations and dynamics of the business and of work performance and how it is measured.

- Participate in strategic planning including the costs and benefits of implementation decisions: $\Rightarrow$ Develop employees for desired skills $\Rightarrow$ Hire new employees with desired skills $\Rightarrow$ Automate (replace employees with machines) $\Rightarrow$ Outsource for desired skills

\section{Failing to demonstrate effectiveness and} ROI

Despite having the means to do so, HRD has been criticized for not demonstrating its effectiveness and ROI.
To demonstrate effectiveness and ROI, HRD needs to

- Constantly collect quantifiable and anecdotal evidence of HRD's effectiveness

- $\quad$ Adopt data-driven HRD decision-making. Develop partnerships with institutions that offer employees cost-effective continuing education and training.

\section{Focusing on marginal programs}

HRD offers programs of marginal alue at the expense of those that address important business and workforce needs.
To refocus on learning and development initiatives that are meaningful for employees and their organization, HRD should

- $\quad$ Prioritize programs and support for initiatives that help the organization to meet key business needs and to address challenges in today's changing work environment.

- $\quad$ Provide support for programs based on learning paths that shift the emphasis away from formal HRD and the HRD practitioner toward more reliance on employee reflection, self-direction, and experience-based learning.

\section{Providing content without needs analysis} With the proliferation of online content, HRD is criticized for making online learning content available without providing the needs analysis that links each content area to a corresponding learning need, thus side-stepping its responsibility for matching L\&D with employee learning needs.
To ensure that learning offerings meet learning needs, HRD needs to

- Assure that online learning content is accompanied by the needs analysis that links each content area to a corresponding learning need.

- $\quad$ Support the development of human capabilities such as systems thinking, creativity, collaboration, and resilience that cannot be replaced or duplicated by technology, artificial intelligence, automation, and decision-making algorithms. 


\section{Table 1 (continued)}

Dilemmas, challenges, and criticisms of HRD

5. Bringing in insufficient firsthand knowledge of work and the workplace

As firsthand knowledge of the work itself has diminished in importance to HRD, it has been criticized for not taking advantage of the developmental opportunities of work experience as HRD is unaware of what the work itself entails.

Beyond HRD research on knowledge work and workforce development, little attention has been given to this area.
Implications for change (the transformation of HRD)

Rather than waiting for the results of work redesign projects completed by others, HRD needs to

- Be an active participant in work redesign so that new work processes take advantage of employee strengths and skill sets.

- $\quad$ Revitalize interest in, and acquire firsthand knowledge of, the work itself, its origins, and engagement in workplace studies as the basis of authentic work-based learning. 